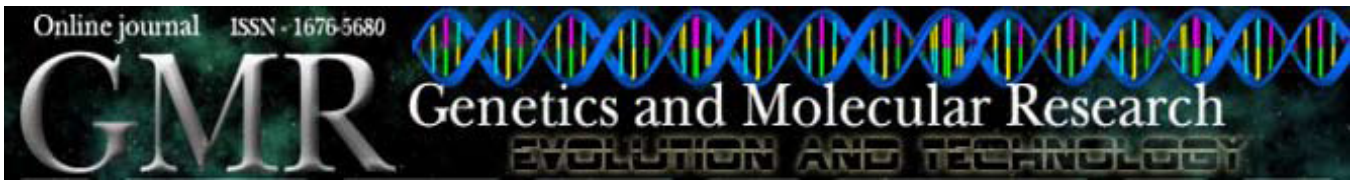

\title{
Polymorphisms in the IGF1 gene and their effect on growth traits in Mexican beef cattle
}

\author{
X.F. De la Rosa Reyna ${ }^{1}$, H.M. Montoya ${ }^{2}$, V.V. Castrellón ${ }^{3}$, \\ A.M.S. Rincón ${ }^{1}$, M.P. Bracamonte ${ }^{1}$ and W.A. Vera ${ }^{1}$ \\ ${ }^{1}$ Instituto Politécnico Nacional, Centro de Biotecnología Genómica, \\ Reynosa, Tamaulipas, México \\ ${ }^{2}$ Texas A\&M University, Department of Wildlife and Fisheries, \\ College Station, Texas, USA \\ ${ }^{3}$ Instituto Tecnológico del Valle del Guadiana, V. Montemorelos, \\ Durango, México \\ Corresponding author: X.F. De la Rosa Reyna \\ E-mail: xdelarosa@ipn.mx
}

Genet. Mol. Res. 9 (2): 875-883 (2010)

Received January 3, 2010

Accepted February 15, 2010

Published May 11, 2010

DOI 10.4238/vol9-2gmr745

\begin{abstract}
The IGF1 gene (insulin-like growth factor 1) is a candidate gene for marker-assisted selection strategies. A single nucleotide polymorphism in the promoter region (IGF1/SnaBI) has been reported to be associated with production traits in several cattle breeds. Here, we report its allelic frequencies in Charolais and Beefmaster breeds; we confirm its association with three growth traits: weaning weight, weaning weight adjusted to 210 days and preweaning weight gain in the Charolais breed. In addition, we designed a strategy to search these breeds for new polymorphisms in four coding regions of the gene. A C/A transversion was detected in intron 4, but it was not associated with the growth traits. A single nucleotide polymorphism (IGF1/SnaBI) is proposed as a selection marker for Mexican Charolais cattle; validation of its association with weaning weight, weaning weight adjusted to 210 days and preweaning weight gain, could complement the genetic evaluations of this breed through marker-assisted management strategies.
\end{abstract}

Key words: IGF1; SNP IGF1/SnaBI; Polymorphism;

Charolais; Beefmaster 


\section{INTRODUCTION}

In vertebrates, the insulin-like growth factor 1 (IGF1) or somatomedin gene plays a key role in various physiological and metabolic processes, where IGF1 and growth hormone or somatotrophin are involved in the somatotropic axis. IGF1 is a mediator of many biological effects; for example, it increases the absorption of glucose, stimulates myogenesis, inhibits apoptosis, participates in the activation of cell cycle genes, increases the synthesis of lipids, stimulates the production of progesterone in granular cells, and intervenes in the synthesis of DNA, protein, RNA, and in cell proliferation (Etherton, 2004).

The bovine IGF1 gene was mapped on chromosome 5, in the centimorgan 73.5 (Grosse et al., 1999). The provisional nucleotide sequence is approximately $72 \mathrm{~kb}$ (ID number 281239). In humans, pigs, goats, rats, and chickens, the IGF1 nucleotide sequence is about 70-90 kb (Shimatsu and Rotwein, 1987; Kajimoto and Rotwein, 1991; Rose, 2002). Exon number is different between species; for example, goats, pigs and sheep have 1-6 exons (Mikawa et al., 1995), and humans and rats 1-5 (Rotwein et al., 1986; Shimatsu and Rotwein, 1987). Wang et al. (2003) reported that bovine IGF1 has 6 exons responsible for expressing heterogeneous mRNA. Like other species, depending on the exon leader present, two transcripts are identified, class 1 (exon 1 as the leader) or class 2 (exon 2 as the leader). In class 1 transcripts, there are three transcription start sites, whereas class 2 has one. Although the length and genetic structure between species is variable, the expressed protein of 70 amino acids is highly conserved in vertebrates (Upton et al., 1998). Fotsis et al. (1990), in a comparative study of the IGF-IA precursor between human and bovine, identified a conservation of around 93 and $96 \%$ in nucleotide and amino acid sequences, respectively. Due to its biological function, the IGF1 gene is considered to be a candidate gene for predicting growth and meat quality traits in animal genetic improvement schemes (Machado et al., 2003; Andrade et al., 2008). The bovine IGF1 gene has two polymorphisms located in the promoter region: a $\mathrm{CA}_{\mathrm{n}}$ microsatellite (Kirkpatrick, 1992), and a T/C transition, also known as the single nucleotide polymorphism (SNP) IGF1/SnaBI (Ge et al., 1997, 2001). The microsatellite has been associated with birth weight and weaning in Hereford cattle, but these associations were not found in breeds such as Nellore, Canchim and Simental/Angus crosses studied by Curi et al. (2005a). After its evaluation with growth characteristics in Angus cattle, the SNP IGF1/SnaBI was considered to be a potential molecular marker associated with weight gain during the first 20 days after weaning (Ge et al., 2001). Curi et al. (2005b) studied some Nellore, Canchim and several population crosses and found a significant association of SNP with body weight and subcutaneous backfat. Li et al. (2004) analyzed the association between SNP and growth characteristics and found an unstable association between the BB genotype with birth weight, average daily gain and average daily preweaning in Beefbooster cattle. Although there is no evidence of a functional role in gene expression, these polymorphisms are considered to be potential molecular markers (Siadkowska et al., 2006), and it has even been proposed that the existence of other polymorphic sites linked with these markers will help to explain the effect of the IGF1 gene on phenotypic characteristics.

In this study, the effect of the SNP IGF1/SnaBI on growth characteristics was determined in Mexican beef cattle. In addition, we made a search for new polymorphisms in four coding regions of the IGF1 gene. 


\section{MATERIAL AND METHODS}

Using Promega Wizard ${ }^{\circledR}$ (Promega Corporation, Madison, WI, USA), DNA was isolated from blood samples obtained from Charolais (group 1) and Beefmaster (group 2) breeds. Group 1 comprised 68 animals with different background, 25 dams from a nucleus herd that had been selected for improved lean beef and calving ease using founders from England, France and Ireland, while the other 43 corresponded to sires of 12 different herds and confined to be evaluated for feedlot response. These populations were located in Nuevo León and Coahuila, Mexico, respectively. Group 2 consisted of 25 Beefmaster sires from a herd located in Tamaulipas, Mexico.

\section{Analysis of the IGF1/SnaBI polymorphism}

The IGF1/SnaBI marker was analyzed using a modification of the procedure reported by $\mathrm{Ge}$ et al. (1997). Briefly, we used a nested-polymerase chain reaction (PCR) using the primers IGF1-E1 (Table 1). We then performed a nested-PCR with the previously reported primers (IGF677F 5'-ATTACAAAGCTGCCTGCCCC-3'; IGF897R 5'-ACCTTACCCGTATGAAAGGAATATACGT-3'). After enzymatic digestion with SnaBI, alleles A (223, $26 \mathrm{bp})$ and B (249 bp) were analyzed on 20\% polyacrylamide gels (Sigma-Aldrich).

\section{Detection of new polymorphisms in IGF1}

Using the sequences reported in the NCBI AF210383, AF210384, AF210385, and AF210386 and Primer Select 4.03 (DNASTAR Inc.; Anonymous, 2008) primers were designed to amplify the adjacent regions of exons 1,2,3, and 4 of the gene (Table 1). To identify the polymorphic sites, we amplified the four gene regions using DNA from five different individuals of each breed. PCR products were cloned in the TOPO XL system (PCR Cloning Kit, Invitrogen). SequiTherm EXCEL ${ }^{\mathrm{TM}}$ II DNA Sequencing Kit (Epicentre Technologies, Madison, WI, USA) was used for bidirectional sequencing of plasmid DNA obtained individually in each clone. Sequence edition was done with the E-Seq program (LI-COR IR2 DNA Sequencer) and assembled with CAP3 (Huang and Madan, 1999). At least 3 different clones were sequenced from each fragment and breed.

\begin{tabular}{lllc}
\multicolumn{2}{l}{ Table 1. Primers used in the amplification of coding regions in the bovine IGF1 gene. } & PCR product \\
\hline & Sequence 5'-3' & Sequence 3'-5' & 785 bp \\
\hline IGF-E1 & GGGCAAAAAGCATGAGACAGT & GCTGATTTTTCCCATTGCTTCTGA & 390 bp \\
IGF-E2 & GCCAGCAGCTCACAAGCTGA & ACCATTTTTGTGTTCCAGAT & 362 bp \\
IGF-E3 & TTGCACTCCTGGAAGGGGCATA & TCTTCGCACACTCCCCGGCAGTT & 341 bp \\
IGF-E4 & CCACTCTAAAGCTAGGCCTCTCTC & GAAGTCTATGAGGGTATGAAT & \\
\hline
\end{tabular}

$\mathrm{PCR}=$ polymerase chain reaction .

Multiple alignment of sequences was done with ClustalW2 (Larkin et al., 2007), comparing the new sequences with those previously reported (AF210383, AF210384, AF210385, and AF210386) and the provisional sequence reported for the bovine genome (ID number 281239).

For genotyping purposes, three different assays were designed and tested in Beefmaster and Charolais samples. Table 2 shows the PCR/RFLP (restriction fragment length 
polymorphism), a restriction site insertion (RSI/RFLP) and allele specific PCR (PASA) tests. The PASA assay was performed in a final volume of $25 \mu \mathrm{L}$ using two primer pairs, one showing a 3'-modified primer and the other $26 \mathrm{bp}$ and GC-rich at the 5' end. The reaction mixtures for the three assays consisted of $100 \mathrm{ng} \mathrm{DNA}, 2.5 \mathrm{mM} \mathrm{MgCl}, 0.2 \mathrm{mM}$ dNTPs, $5 \mu \mathrm{M}$ of each primer and $1 \mathrm{U}^{\mathrm{AmpliTaq}}{ }^{\circledR}$ DNA Polymerase-Fragment Stoffel (Applied Biosystems). The PCR profile used in all assays was: $95^{\circ} \mathrm{C}$ for $5 \mathrm{~min}, 95^{\circ} \mathrm{C}$ for $45 \mathrm{~s}, 65^{\circ} \mathrm{C}$ for $45 \mathrm{~s}$ (two cycles), $95^{\circ} \mathrm{C}$ for $45 \mathrm{~s}, 65^{\circ} \mathrm{C}$ for $45 \mathrm{~s}, 72^{\circ} \mathrm{C}$ for $45 \mathrm{~s}(5$ cycles decreasing $2^{\circ} \mathrm{C}$ in each cycle), $95^{\circ} \mathrm{C}$ for $45 \mathrm{~s}, 60^{\circ} \mathrm{C}$ for $45 \mathrm{~s}, 72^{\circ} \mathrm{C}$ for $45 \mathrm{~s}(25$ cycles), and $72^{\circ} \mathrm{C}$ for $10 \mathrm{~min}$. For the PCR-RFLP assay, we digested $150 \mathrm{ng}$ PCR product with 5 $\mathrm{U}$ enzyme (Promega Corporation) in a final volume of $10 \mu \mathrm{L}$. The digestion pattern was visualized on $6 \%$ polyacrylamide gels (Sigma-Aldrich).

\begin{tabular}{|c|c|c|c|c|}
\hline & Sequence 5'-3' & Localization & PCR product & Technique \\
\hline IGF-66F & GCTGCCTGCCCCTTTCCAaG & 5'UTR & $785 \mathrm{bp}$ & $\mathrm{RSI} / A l u \mathrm{I}$ \\
\hline IGF- 66-95R & GGCGTGAAGACACACACATC & & & \\
\hline IGF95NF & TGAGATCATTCCCCTCACTT & & & \\
\hline IGF95MF & $\begin{array}{l}\text { GCGGGCAGGGCGGCGGGGGCGGGGCC } \\
\text { TGAGATCATTCCCCTCACTc }\end{array}$ & 5'UTR & $240 \mathrm{bp}$ & PASA \\
\hline IGF66-95R & GGCGTGAAGACACACACATC & & & \\
\hline IGF32NF & GAAGGGGCATAGTTTTGATTT & Intron 2 & $178 \mathrm{bp}$ & PASA \\
\hline IGF32MF & $\begin{array}{l}\text { GCGGGCAGGGCGGCGGGGGCGGGGCC } \\
\text { GAAGGGGCATAGTTTTGATTa }\end{array}$ & & & \\
\hline IGF32R & AAGCACAGGGCCAGATAGAA & & & \\
\hline IGF-E4F & ССАCTCTAAAGCTAGGCCTCTCTC & Intron 4 & $341 \mathrm{bp}$ & $\mathrm{PCR} /$ NruI \\
\hline IGF-E4R & GAAGTCTATGAGGGTATGAAT & & & \\
\hline IGF-270 & TCGGCCATCTTCGCGcaAT & Intron 4 & $264 \mathrm{bp}$ & $\mathrm{RSI} / M f e \mathrm{I}$ \\
\hline IGF-E4R & GAAGTCTATGAGGGTATGAAT & & & \\
\hline
\end{tabular}

$\mathrm{UTR}=$ untranslated region; $\mathrm{PCR}=$ polymerase chain reaction; $\mathrm{RSI}=$ restriction site insertion; PASA = allele specific PCR.

\section{Polymorphism association with growth traits}

According to data availability from the Charolais and Beefmaster populations, we evaluated the association of IGF1 SNPs with growth traits including birth weight (BW), weaning weight (WW), weaning weight adjusted to 210 days (WW210), preweaning weight gain (WG), weight adjusted to 400 days (W400), postweaning weight gain (PWG), weight adjusted to 600 days (W600), and daily weight gain to 600 days (G600).

The procedure used for the analysis of the association was the general linear model of the statistics package SAS, with the following model:

$$
\mathrm{Y}_{\mathrm{ijk}}=\mu+\mathrm{GS}_{\mathrm{i}}+\mathrm{GN}_{\mathrm{j}}+\mathrm{BW}+\varepsilon_{\mathrm{ij}}
$$

where $Y_{\mathrm{ijk}}=$ dependent variable (WW, WW210, WG, W400, PWG, W600, G600); $\mu$ = general average; $\mathrm{GS}_{\mathrm{i}}=$ effect of the $\mathrm{i}$-th genotype of IGF1/SnaBI (AA, AB, BB); $\mathrm{GN}_{\mathrm{j}}=\mathrm{j}$-th genotype of IGF1/NruI (AA, AB, BB); BW = birth weight effect as linear covariable for all variables except $\mathrm{BW}$, and $\varepsilon_{\mathrm{ij}}=$ random error. The least square means were compared by the Tukey method in the same statistics package (SAS, 2000). 


\section{RESULTS}

\section{Allelic and genotypic frequencies of the IGF1/SnaBI polymorphism}

Allelic and genotypic frequencies obtained in the two breeds studied are shown in Table 3. In the Beefmaster population, the favorable allele B was found at a high frequency (0.97). The two Charolais populations showed frequency differences according to their geographic origin and sex. In the sires from Coahuila, the favorable allele B (0.74) had a high frequency, while in the group of Charolais females (Nuevo Léon), the frequencies were $0.21,0.50$ and 0.29 for $\mathrm{AA}, \mathrm{AB}$ and $\mathrm{BB}$ genotypes, respectively. In this last population, the allelic frequencies are approximately those expected for a population in equilibrium (allele $\mathrm{A}=0.46$ and allele $\mathrm{B}=0.54$ ).

Table 3. Allelic and genotypic frequencies of IGF1/SnaBI observed in Charolais and Beefmaster breeds.
\begin{tabular}{lccccc}
\hline Population & \multicolumn{4}{c}{ Frequencies } \\
\cline { 2 - 6 } & A & B & AA & AB & BB \\
\hline Charolais (Coahuila) & 0.26 & 0.74 & 0.070 & 0.372 & 0.558 \\
Charolais (Nuevo León) & 0.46 & 0.54 & 0.208 & 0.500 & 0.292 \\
Beefmaster (Tamaulipas) & 0.03 & 0.97 & 0.00 & 0.067 & 0.933 \\
\hline
\end{tabular}

Association analysis of the SNP IGF1/SnaBI was performed only in Charolais females, since the three genotypes were detected in HW proportions. The Beefmaster breed was omitted because allele B was practically fixed in the population studied. In this analysis, the SNP IGF1/SnaBI showed a significant effect $(\mathrm{P}<0.05)$ on three production traits, WW $(\mathrm{P}=$ $0.039)$, WW210 ( $\mathrm{P}=0.041)$ and $\mathrm{WG}(\mathrm{P}=0.0148)$ (Table 4).

\section{Table 4. Least square means \pm standard error of the SNP IGF1/SnaBI genotypes.}

\begin{tabular}{|c|c|c|c|}
\hline \multirow[t]{2}{*}{ Growth trait } & \multicolumn{3}{|c|}{ Genotypes } \\
\hline & AA & $\mathrm{AB}$ & BB \\
\hline BW & $42.215 \pm 3.19^{\mathrm{a}}$ & $42.479 \pm 2.21^{\mathrm{a}}$ & $46.110 \pm 2.55^{\mathrm{a}}$ \\
\hline WW (kg) & $214.517 \pm 28.99^{b}$ & $301.201 \pm 20.36^{\mathrm{a}}$ & $268.949 \pm 24.86^{\mathrm{a}, \mathrm{b}}$ \\
\hline WW210 (kg) & $198.059 \pm 21.22^{b}$ & $260.292 \pm 15.16^{\mathrm{a}}$ & $225.878 \pm 18.12^{\mathrm{a}, \mathrm{b}}$ \\
\hline WG $(\mathrm{kg})$ & $0.692 \pm 0.11^{\mathrm{b}}$ & $1.058 \pm 0.07^{\mathrm{a}}$ & $0.832 \pm 0.09^{\mathrm{a}, \mathrm{b}}$ \\
\hline W400 (kg) & $340.129 \pm 34.43^{\mathrm{a}}$ & $392.373 \pm 27.23^{\mathrm{a}}$ & $361.014 \pm 25.23^{\mathrm{a}}$ \\
\hline PWG (g) & $0.788 \pm 0.23^{\mathrm{a}}$ & $0.647 \pm 0.17^{\mathrm{a}}$ & $0.710 \pm 0.16^{\mathrm{a}}$ \\
\hline W600 (kg) & $437.082 \pm 18.80^{\mathrm{a}}$ & $404.684 \pm 17.93^{\mathrm{a}}$ & $459.458 \pm 10.78^{a}$ \\
\hline $\mathrm{G} 600(\mathrm{~g})$ & $0.783 \pm 0.16^{\mathrm{a}}$ & $0.817 \pm 0.13^{\mathrm{a}}$ & $0.553 \pm 0.13^{\mathrm{a}}$ \\
\hline
\end{tabular}

Effects on growth traits in Charolais breed. $\mathrm{BW}=$ body weight; $\mathrm{WW}=$ weaning weight; $\mathrm{WW} 210=$ weaning weight adjusted to 210 days; $\mathrm{WW}=$ preweaning weight gain; $\mathrm{W} 400=$ weight adjusted to 400 days; $\mathrm{PWG}=$ postweaning weight gain; W600 = weight adjusted to 600 days; G600 = daily weight gain to 600 days; a,b,c: significantly different means between genotypes.

\section{New polymorphic sites in IGF1}

Five mutations were located in the IGF1 gene from the Charolais and Beefmaster breeds: two transitions in 5'UTR, 1 indel in intron 2, 1 transition and 1 transversion in intron 4 (Table 5). Genotyping results validated as a true polymorphism only the transversion C/T located in intron 4. As shown in Table 2, the PCR-RFLP assay relies on the use of restriction enzyme NruI, which recognizes the sequence TCG/CGA; when the transversion is present, the 
restriction site is modified and lost (TCG/AGA). The alleles were called A (nucleotide C) and $\mathrm{B}$ (nucleotide $\mathrm{A}$ ). The frequency of the polymorphism was determined in the populations studied, as shown in Table 6 . The Beefmaster population had higher frequencies of allele B $(0.70)$, and contrasting allelic frequencies were found in the two Charolais populations, where allele A was more prevalent $(0.72)$ in the Coahuila population and allele B in the Nuevo León population (0.52). The association analysis of the intron $4 / \mathrm{NruI}$ polymorphism was not significant $(\mathrm{P}>0.05)$ for the growth traits tested in either the Charolais or Beefmaster breed (Table 7).

\begin{tabular}{|c|c|c|c|}
\hline Contig position & Reference sequence position (ID number 281239) & Location & Nucleotide change \\
\hline 66 & 66 & 5'UTR & $\mathrm{T} / \mathrm{C}$ \\
\hline 95 & 95 & 5'UTR & $\mathrm{T} / \mathrm{C}$ \\
\hline 32 & 4632 & Intron 2 & $\mathrm{~T} /-$ \\
\hline 264 & 56392 & Intron 4 & $\mathrm{C} / \mathrm{A}$ \\
\hline 270 & 56398 & Intron 4 & $\mathrm{~T} / \mathrm{C}$ \\
\hline
\end{tabular}

\begin{tabular}{|c|c|c|c|c|c|}
\hline \multirow[t]{2}{*}{ Population } & \multicolumn{5}{|c|}{ Frequencies } \\
\hline & $\mathrm{A}(264,77 \mathrm{bp})$ & B (341 bp) & AA & $\mathrm{AB}$ & BB \\
\hline Charolais (Coahuila) & 0.48 & 0.52 & 0.442 & 0.070 & 0.488 \\
\hline Charolais (Nuevo León) & 0.72 & 0.28 & 0.520 & 0.400 & 0.080 \\
\hline Beefmaster (Tamaulipas) & 0.30 & 0.70 & 0.080 & 0.440 & 0.480 \\
\hline
\end{tabular}

\begin{tabular}{|c|c|c|c|}
\hline \multirow[t]{2}{*}{ Growth trait } & \multicolumn{3}{|c|}{ Genotypes } \\
\hline & $\mathrm{AA}$ & $\mathrm{AB}$ & BB \\
\hline BW & $42.93 \pm 1.88^{\mathrm{a}}$ & $42.56 \pm 2.11^{\mathrm{a}}$ & $45.30 \pm 4.52^{\mathrm{a}}$ \\
\hline WW & $253.40 \pm 17.41^{\mathrm{a}}$ & $290.90 \pm 20.10^{\mathrm{a}}$ & $240.36 \pm 41.40^{\mathrm{a}}$ \\
\hline WW210 & $215.78 \pm 13.03^{\mathrm{a}}$ & $252.41 \pm 14.71^{\mathrm{a}}$ & $216.04 \pm 30.24^{a}$ \\
\hline WG & $0.819 \pm 0.66^{\mathrm{a}}$ & $0.947 \pm 0.07^{\mathrm{a}}$ & $0.816 \pm 0.15^{\mathrm{a}}$ \\
\hline W400 & $365.66 \pm 17.08^{\mathrm{a}}$ & $379.74 \pm 21.04^{\mathrm{a}}$ & $348.12 \pm 60.04^{\mathrm{a}}$ \\
\hline PWG & $0.933 \pm 0.11^{\mathrm{a}}$ & $0.663 \pm 0.13^{\mathrm{a}}$ & $0.551 \pm 0.39^{\mathrm{a}}$ \\
\hline W600 & $488.96 \pm 8.30^{\mathrm{a}}$ & $416.28 \pm 18.76^{a}$ & $395.99 \pm 27.22^{a}$ \\
\hline G600 & $0.579 \pm 0.09^{\mathrm{a}}$ & $0.978 \pm 0.16^{\mathrm{a}}$ & $0.596 \pm 0.18^{\mathrm{a}}$ \\
\hline
\end{tabular}

Effects on growth traits in Charolais breed. $\mathrm{BW}=$ body weight; $\mathrm{WW}=$ weaning weight; $\mathrm{WW} 210=$ weaning weight adjusted to 210 days; $W G=$ preweaning weight gain; $W 400=$ weight adjusted to 400 days; $P W G=$ postweaning weight gain; W600 = weight adjusted to 600 days; G600 = daily weight gain to 600 days. a,b,c: significantly different means between genotypes.

\section{DISCUSSION}

IGF1 is located on bovine chromosome 5, which to date harbors at least 73 quantitative trait loci (QTL) (Animal QTL Database, 2009; http://www.animalgenome.org/QTLdb/). Due to the high QTL number close to IGF1, this chromosomal region has been evaluated not only in different species of domestic animals but also between different breeds for example in cattle (Casas-Carrillo et al., 1997; Li et al., 2006; Bian et al., 2008; Stratikopoulos et al., 2008).

The SNP IGF1/SnaBI has been studied in more than 20 cattle breeds, including dairy and beef breeds. The allelic frequencies reported for the favorable B allele vary from 0.16 to 
1.0 (Curi et al., 2005b; Li et al., 2006). There are contrasting allelic frequencies in Beefmaster and Charolais breeds. In the Beefmaster population, the B allele was almost fixed (0.97), and Curi et al. (2005b) proposed that allele B is characteristic of indicus populations because they found it fixed in a Nellore population. The high frequency in Beefmaster could therefore be due to its composition, which includes an indicus background. The Charolais populations evaluated had been selected mainly for improved growth traits. The frequency of the favorable allele B in the two Charolais groups evaluated was 0.54 and 0.74 . This result is interesting since the greater frequency of the BB genotype (0.558) was observed in the population from Coahuila, represented by sires that could be considered as seed-stock for the Mexican Charolais Full-French in Mexico. Although the frequency of the favorable allele B was lower in the dam population (Nuevo León) than in the sires, the frequency of the heterozygote $A B$ genotype was greater, where through adequate reproduction management it could be possible to increase the frequency of the homozygote BB genotype.

The association of the SNP IGF1/SnaBI was confirmed in the Charolais breed, where $\mathrm{AB}$ and $\mathrm{BB}$ genotypes showed a significant effect on WW, WW210 and WG. Our results are consistent with those previously reported in Angus, Nellore and Holstein-Friesian breeds, where a dominance effect of allele B over allele A was observed, affecting traits such as: PWG, body weight at sacrifice and daily weight gain (Ge et al., 2001; Curi et al., 2005b; Siadkowska et al., 2005). The SNP IGF1/SnaBI has shown inconsistencies in validation tests to probe its association with growth traits. It has been proposed that when a marker association discovery occurs in the Gene-SNP/trait direction, different factors should affect the association, for example, the genetic background of the animals studied, the selection, gene drift, linkage disequilibrium between genes of greater effect (positive or negative), linkage disequilibrium between marker/ trait, and epistatic interactions (Machado et al., 2003). The effect of these factors combined with the large number of QTL identified on chromosome 5, would help explain the possible inconsistencies of the association of the IGF/SnaBI polymorphism with growth traits.

Nevertheless, for the genetic improvement of animals, this type of molecular marker has been integrated as part of the selection criteria to complement the genetic evaluations of production traits in cattle (Dekkers, 2004). When they are in linkage disequilibrium and in phase with functional genetic variation, they provide information on the genetic merit of the animals even after several generations (Stone et al., 2005). Ríos et al. (2007) reported the first data of heritability on growth characteristics in the Mexican Charolais breed: 0.22 for birth weight, 0.33 for adjusted weaning weight (205 days) and 0.45 for postweaning weight gain. The moderate heritability of these characteristics would be favored with the use of the SNP IGF/SnaBI in programs of marker-assisted management. However, it is important to validate our association results in a greater number of Charolais populations. This approach could be also useful to test the C/A transversion located in intron 4 in Mexican Beefmaster and Charolais breeds. Although we did not probe any association of the new C/A polymorphism with growth traits, its potential as a marker is not discarded. Some polymorphic sites located in introns have been useful as molecular markers. For example, with regard to the $\mu$-calpain gene (CAPN1), the predictive value of the CAPN1 4751 marker for shear force has been validated. This marker is found in intron 17, and its functional role has not yet been determined (White et al., 2005).

Due to the high degree of conservation in coding regions of the IGF1 gene, which was confirmed in our study, the search for causal polymorphisms has been extended to other genes of this system, including the two classes of growth factors (IGF1 and IGF2), the receptors 
(IGF1R and IGF2R) and the six binding proteins (IGFBP1-6) (Machado et al., 2003). This global search is an alternative approach in genetic studies of Mexican cattle populations.

\title{
ACKNOWLEDGMENTS
}

\author{
Research supported by Instituto Politécnico Nacional (\#SIP20040309 and \\ \#SIP20050192).
}

\section{REFERENCES}

Anonymous (2008). Primer Select DNASTAR Software Version 8.02. DNASTAR, Inc., Madison.

Andrade PC, Grossi DA, Paz CC, Alencar MM, et al. (2008). Association of an insulin-like growth factor 1 gene microsatellite with phenotypic variation and estimated breeding values of growth traits in Canchim cattle. Anim. Genet. 39: 480-485.

Animal QTLDatabase (2009). Available at [http://www.animalgenome.org/QTLdb/]. Accessed April 20, 2009.

Bian LH, Wang SZ, Wang QG, Zhang S, et al. (2008). Variation at the insulin-like growth factor 1 gene and its association with body weight traits in the chicken. J. Anim. Breed. Genet. 125: 265-270.

Casas-Carrillo E, Prill-Adams A, Price SG, Clutter AC, et al. (1997). Relationship of growth hormone and insulin-like growth factor-1 genotypes with growth and carcass traits in swine. Anim. Genet. 28: 88-93.

Curi RA, Oliveira HN, Silveira AC and Lopes CR (2005a). Effects of polymorphic microsatellites in the regulatory region of IGF1 and GHR on growth and carcass traits in beef cattle. Anim. Genet. 36: 58-62.

Curi RA, de Oliveira HN, Silveira AC and Lopes CR (2005b). Association between IGF-I, IGF-IR and GHRH gene polymorphisms and growth and carcass traits in beef cattle. Livest. Sci. 94: 159-167.

Dekkers JC (2004). Commercial application of marker- and gene-assisted selection in livestock: strategies and lessons. $J$. Anim. Sci. 82 (E-Suppl): E313-E328.

Etherton TD (2004). Somatotropic function: the somatomedin hypothesis revisited. J. Anim. Sci. 82 (E-Suppl): E239-E244.

Fotsis T, Murphy C and Gannon F (1990). Nucleotide sequence of the bovine insulin-like growth factor 1 (IGF-1) and its IGF-1A precursor. Nucleic Acids Res. 18: 676.

Ge W, Davis ME and Hines HC (1997). Two SSCP alleles detected in the 5'-flanking region of bovine IGF1 gene. Anim. Genet. 28: 155-156.

Ge W, Davis ME, Hines HC, Irvin KM, et al. (2001). Association of a genetic marker with blood serum insulin-like growth factor-I concentration and growth traits in Angus cattle. J. Anim. Sci. 79: 1757-1762.

Grosse WM, Kappes SM, Laegreid WW, Keele JW, et al. (1999). Single nucleotide polymorphism (SNP) discovery and linkage mapping of bovine cytokine genes. Mamm. Genome 10: 1062-1069.

Huang X and Madan A (1999). CAP3: A DNA sequence assembly program. Genome Res. 9: 868-877.

Kajimoto Y and Rotwein P (1991). Structure of the chicken insulin-like growth factor I gene reveals conserved promoter elements. J. Biol. Chem. 266: 9724-9731.

Kirkpatrick BW (1992). Identification of a conserved microsatellite site in the porcine and bovine insulin-like growth factor-I gene 5' flank. Anim. Genet. 23: 543-548.

Larkin MA, Blackshields G, Brown NP, Chenna R, et al. (2007). Clustal W and Clustal X version 2.0. Bioinformatics 23: 2947-2948.

Li C, Basarab J, Snelling WM, Benkel B, et al. (2004). Assessment of positional candidate genes myf5 and igf1 for growth on bovine chromosome 5 in commercial lines of Bos taurus. J. Anim. Sci. 82: 1-7.

Li MH, Adamowicz T, Switonski M, Ammosov I, et al. (2006). Analysis of population differentiation in North Eurasian cattle (Bos taurus) using single nucleotide polymorphisms in three genes associated with production traits. Anim. Genet. 37: 390-392.

Machado MBB, Alencar MM, Pereira AP, Oliveira HN, et al. (2003). QTL affecting body weight in a candidate region of cattle chromosome 5. Genet. Mol. Biol. 26: 259-265.

Mikawa S, Yoshikawa G, Aoki H, Yamano Y, et al. (1995). Dynamic aspects in the expression of the goat insulin-like growth factor-I (IGF-I) gene: diversity in transcription and post-transcription. Biosci. Biotechnol. Biochem. 59: 87-92.

Ríos Utrera A, Velázquez GM, Tsuruta S, Bertrand JK, et al. (2007). Estimates of genetic parameters for growth traits of Mexican Charolais cattle. Tec. Pecu. Mex. 45: 121-130.

Rose MT (2002). The somatotropic axis of the dairy cow revisited. Anim. Sci. J. 73: 13-19. 
Rotwein P, Pollock KM, Didier DK and Krivi GG (1986). Organization and sequence of the human insulin-like growth factor I gene. Alternative RNA processing produces two insulin-like growth factor I precursor peptides. J. Biol. Chem. 261: 4828-4832.

SAS Institute (2000). Statistical Analysis System, Systems for Windows. SAS Institute Inc., Cary.

Shimatsu A and Rotwein P (1987). Mosaic evolution of the insulin-like growth factors. Organization, sequence, and expression of the rat insulin-like growth factor I gene. J. Biol. Chem. 262: 7894-7900.

Siadkowska E, Zwierzchowski L, Oprzadek J and Strzalkowska N (2006). Effect of polymorphism in IGF-1 gene on production traits in Polish Holstein-Friesian cattle. Anim. Sci. Pap. Rep. 3: 225-237.

Stone RT, Casas E, Smith TP, Keele JW, et al. (2005). Identification of genetic markers for fat deposition and meat tenderness on bovine chromosome 5: development of a low-density single nucleotide polymorphism map. J. Anim. Sci. 83: 2280-2288.

Stratikopoulos E, Szabolcs M, Dragatsis I, Klinakis A, et al. (2008). The hormonal action of IGF1 in postnatal mouse growth. Proc. Natl. Acad. Sci. U. S. A. 105: 19378-19383.

Upton Z, Yandell CA, Degger BG, Chan SJ, et al. (1998). Evolution of insulin-like growth factor-I (IGF-I) action: in vitro characterization of vertebrate IGF-I proteins. Comp. Biochem. Physiol. B Biochem. Mol. Biol. 121: 35-41.

Wang Y, Price SE and Jiang H (2003). Cloning and characterization of the bovine class 1 and class 2 insulin-like growth factor-I mRNAs. Domest. Anim. Endocrinol. 25: 315-328.

White SN, Casas E, Wheeler TL, Shackelford SD, et al. (2005). A new single nucleotide polymorphism in CAPN1 extends the current tenderness marker test to include cattle of Bos indicus, Bos taurus, and crossbred descent. J. Anim. Sci. 83: 2001-2008. 